\title{
THE BENEFIT OF ISLAMIC FAITH EDUCATION TO ENHANCE CHILDREN SOCIAL AND EMOTIONAL SKILLS
}

\author{
Nuri Sadida \\ Department of Psychology, University of YARSI. \\ Jl. Letjend Soeprapto Kav. 13 Cempaka Putih, Jakarta Pusat, Indonesia, 10510 \\ Email: nuri.sadida@yarsi.ac.id
}

\section{Arif Triman}

Department of Psychology, University of YARSI.

Jl. Letjend Soeprapto Kav. 13 Cempaka Putih, Jakarta Pusat, Indonesia, 10510

Email: arif.triman@mail.yarsi.ac.id

Received: 12, 2017. Accepted: 01, 2019. Published: 01, 2019.

\begin{abstract}
There is an increasing trend among parents nowadays to choose Islamic elementary school. This has triggered the increasing amount of schools that adopt religious bases such as Kuttab Al-Fatih (KAF), a school that emphasized manner education and Islamic faith teaching. The purposes of this study are to correlate Islamic faith education given by parents and student's social and emotional skills and to compare children's emotional and social skills from parents whose children schooled in KAF and in other schools. The measurement of children's social and emotional skills contains three dimensions: persistence, self-control, and social competence. Meanwhile, faith education by parents was measured using how much parents teach faith indicator. There are 52 parents participated in this study. Results showed there is a significant correlation between faith education and social and emotional skills $(\mathrm{r}=.302, \mathrm{p}<.05)$, and there is no significant difference in social and emotional skills between children who submitted to KAF and to other schools.
\end{abstract}

Keywords: Maktab Method, Religious Approach, Social and Emotional Competence.

\begin{abstract}
ABSTRAK
Terdapat peningkatan tren diantara orang tua saat ini yang memilih sekolah dasar Islam. Hal ini menyebabkan bertambabnya sekolah yang menyediakan kurikulum agama seperti Kuttab Al Fatih (KAF), yaitu sekolah yang menekankan pengajaran adab dan keimanan. Tujuan penelitian ini adalah untuk mengetabui korelasi antara pendidikan keimanan yang ditanamkan oleh orang tua dengan kemampuan sosial dan emosional anak, dan untuk. membandingkan kemampuan sosial dan emosional anak yang bersekolah di KAF dan sekolah lain. Pengukuran kemampuan sosial dan emosional anak diukur dengan tiga dimensi yaitu persistensi, kontrol diri, dan kompetensi sosial. Sementara pendidikan keimanan yang dilakukan oleh orang tua diukur melalui seberapa banyak indikator keimanan yang diajarkan orang tua. Responden dalam penelitian ini berjumlah 52 orang tua. Hasil penelitian menunjukekan terdapat korelasi yang signifikan antara pendidikan keimanan dengan kemampuan sosial dan emosional peserta didik ( $r=.302, p<.05)$, dan tidak terdapat perbedaan yang signifikan pada kemampuan sosial dan emosional antara peserta didik yang bersekolah di KAF dan di sekolah lain.
\end{abstract}

Kata Kunci: Pengajaran Maktab, Pendekatan Keagamaan, Kemampuan Sosial dan Emosional.

\section{INTRODUCTION}

All parents want to provide a good education for their children. Some considerations that parents used to evaluate the quality of a school are school beliefs and values, school academic reputation, teaching style, and school culture (Bosetti, 2004). In the past, Muslim parents usually sent their children to top public and or international schools that were being famous 
for high academic standards. But today, they seek a school that can equip students with Islamic character, so that students will successfully perform in a future global economy while avoiding the negative influence of western culture (Bryner, 2011). In addition, Indonesian deputy minister of education also had the concern more on religious instruction in school. It is needed because Indonesian students are deemed not to have character, tolerance, and empathy for others (Schonhardt, 2013). These increasing demands to Islamic school also increased the emergence of Islamic schools in Indonesia.

One of those emerging schools is Kuttab Al-Fatih (KAF), a school with Islamic based, that adopt maktab education model. Maktab is the model of traditional Islamic education since the 10th century BC. It taught basic literacy (such as math, reading, writing, Islamic faith, and Qur'an) with emphasis on Islamic faith education and al-Qur'an. Since the 11th century, scholars Ibn Sina redefined curriculum maktab and split maktab level into two levels, which are primary education and secondary education. Basic education intended for children aged 6 to 14 years, and secondary school (madrasah) intended for children from age 14 years and above (Asimov \& Bosworth, 1999). KAF also positioned themselves as an alternative school, that is a school that offers a different kind of school experiences with a variety of elements that attract students, especially at-risk students (Rosa, 1998). As an alternative school, KAF claimed they have a different approach compared to other Islamic schools. For instance, they believe the more important thing than memorizing al-Qurán is a strong faith, and what more important than learning science is to have good manner. This notion based on principles from Imam Malik, where Imam Malik stated "Manners before knowledge. Faith before al-Qur'an". This means children should have strong faith foundation before intensively learning and memorizing Qur'an. Having a strong faith, according to Imam Malik, means justifying inside the heart, professing by words expression, doing good deeds with all body parts (Wahyudi, 2012). The reason why Islamic faith should be internalized before learning other science is that faith is a source of moral behavior, and moral behavior presupposes faith (Ashraf, 1988). Having strong faith and moral foundation direct every Muslim learning science that intended to help other human beings to go on the right path. Literature in Psychology also revealed the benefit of being religious and involved in religious activities to human's mental health and well-being (Capps, 1995; Weber \& Pargament, 2014), and the ability to adjust with an environment. According to Park, (Park, 2005) spirituality offers a positive meaning-making in coping activity. Spirituality also involved in enhancing effective cognitive processing of stressful events (McIntosh, Silver, \& Wortman, 1993).

Considering the importance of having a strong faith and good manner since early childhood direct KAF to adopt this core principle in daily learning activities. In order to implement faith and manner, every lesson taught in KAF contains principles of Islamic faith. As an illustration, implementing faith teaching to science subject is through activities such as reading al-Qur'an verses that relate to the creation of mountains, sun, oceans, planet, etc. Students were taught to learn the purpose of each Allah's creation, the implied meaning behind the existence of everything in this world, and how individuals should apply a thankful attitude to every living moment. The more or less similar activities also applied to other subjects, such as math, social science, literacy, and many more.

The same thing goes to the manner of teaching. The basic principle of manner teaching is that everything and everyone in this world deserved to be treated with respect. Like any other Islamic school, KAF also trains students to memorize al-Qur'an. But KAF did not give emphasis to how many verses student should memorize, nevertheless, students were more trained to treat al-Qur'an with respect and focus on the importance of having good morality and avoiding over pride as the result of their ability in memorizing al-Qur'an. 
Compared to other Islamic schools, KAF features a distinction that is its perspective about providing students with physical facilities to enhance their learning performance. They believe, the physical facility is not the main aspects of learning. With this belief, many KAF buildings are not made by bricks, but bamboo material. Furthermore, the school also imitates the original learning formation from maktab teaching in ancient time. The illustration of maktab teaching at an ancient time was a sheikh taught a group of students inside a classroom, and students sitting across him on the ground. KAF today also adopts this technique. It provides a class with no chair, and students sit on the ground. Sitting on the ground also refers to technique from Imam Malik by the time he was giving his teaching to caliphate Harun arRasyid. At the beginning of a lesson, Harun ar-Rasyid sat on a chair, meanwhile, Imam Malik and other students sat on the ground. Imam Malik then stated that "Learning enthusiast would appreciate science. Nobody can sit higher than science". The statements made Harun arRasyid sat on the ground together with other students. KAF applies this technique to reduce the potential of feeling arrogance among children.

In addition to the above differences mentioned, KAF puts emphasis on parent's involvement in educating their children. It sets mechanisms to ensure each parent actively involved in the teaching process, particularly at home. This point of view refers to Hadith from Al-Bukhari:

"Every one of you is a shepherd and is responsible for his flock. The leader of people is a guardian and is responsible for his subjects. A man is the guardian of his family and he is responsible for them. A woman is the guardian of his or her husband's home and his children and she is responsible for them. The servant of a man is a guardian of the property of his master and he is responsible for $i$. No doubt, every one of you is a shepherd and is responsible for his flock"

Sahih al-Bukhari 6719, Sahih Muslim 1829 (from Elias, 2011)

The benefit of parent's involvement in educating their children is not only based on Islamic scholars opinion, but also from educational or psychology scholars. According to (Richert \& Barrett, 2005), people's idea of God formed early in the life course. Therefore, parents are showing dominant influence to shape their children's spiritual attitude (Hertel \& Donahue, 1995). They need to invest some quality and quantity of their time to teach religious norms to their children (Bartkowski, 2008). Therefore, KAF always emphasizes that parents must give a higher portion in educating children at home, especially in giving faith education to their children. In this context, KAF only takes a role as facilitator.

Parental active involvement in the learning process at home can also increase the quality of positive relationships between parents and children, where the positive relations will provide the foundation for children's skills. Responsible and sensitive parents help young children develop the skills they need to succeed in life. More than that, early parent-child relationships have powerful effects on children's emotional well-being (Dawson, Ashman, \& Nelson, 2000), their basic coping and problem-solving abilities, and their future capacity for relationships (Lerner \& Castellino, 2002). Through these interactions, children learn skills they need to engage with others and to succeed in different environments (Mey, 2005). They learn how to manage their emotions and behaviors and establish healthy relationships with adults and peers. They also learn how to adjust to new situations and to resolve conflicts (NCPFCE, 2015). Children are required not only to develop social and emotional skills but also increase their literacy development. Parent is responsible for these (Weigel, Martin, \& Bennett, 2006)

Social and emotional skills need to be developed since early childhood. These skills are central to help children to interact and form a relationship with others (Denham \& Weissberg, 2004). Knowing what build a strong social-emotional foundation in a child will later help the child thrive and obtain happiness in life, handle stress and persevere through difficult times in their lives as an adult (Songer, 2009). There are several aspects known as influential factors 
that affect children's social and emotional skill, such as environmental factors, within child factors such as children's temperament, and developmental characteristic (Chen, DeaterDeckard, \& Bell, 2014), parental knowledge of how to react, teach, and interact with their kids characteristics (Wentzel, 2002).

These are variables that had been commonly studied in the development of children social and emotional skills. However, there is a lack of research that tries to seek religiously related variables, such as faith education. A religious approach in developing children's social and emotional skills was believed as a valuable approach since that all religion teaches care, empathy, and concern for others (Bauck, 2015). Faith teaching also plays an important role to provide a sense of meaning and how to cope with stressors in life (Henning, 2011). According to Pollner (1989), religious individuals, especially those who held strong intrinsic faith, tend to see the world, the self, and others in 'healthy-mindedness'.

The lack of research that seeks religious teaching role to social-emotional skills served as a fundamental reason to conduct this study. The first purpose of this study is to seek a correlation between Islamic faith education that parents provide at home with children's social and emotional skills. The second aim of this study is to seek differences in children's social and emotional skills between KAF students and other school's students.

The result of this study can add more theoretical basis to the lack of study in Islamic parenting. This study will also give additional knowledge and confidence for Muslim parents, Islamic school, and school teacher to provide faith teaching for early school age children.

\section{METHOD}

The research participants consisted of parents who have children age of 5-7 years old (early school age). The reason to choose this characteristic is that parents who have kids in early school age have an important role in providing a strong foundation for children to develop optimally (Landry, 2017), especially when children start to developed their social and emotional skills in early school age. The exact number of population for this characteristic is unidentifiable, so this research using the accidental sample to collect participants. Data were taken from offline and online channels. The reason of using online channel is to reach a wider range of parents who schooled their children in Islamic school other than KAF. Meanwhile, the offline channel was used to collect data from parents gathering forum in KAF. Total of 52 parents participated in this study. Surveys were collected over one and a half month around July to September 2016. Parents required to state how frequent they teach faith education and how they perceived their children social and emotional skills.

Islamic Faith Education was measured using a 28 items questionnaire. This questionnaire measured the frequency of delivering Islamic faith education from parents to their children. Islamic faith indicators itself was derived from Ibn Thaimiyah Islamic faith concept. The reason to use Islamic faith concept from Ibn Thaimiyah is that according to the history of Islamic science, Ibn Thaimiyah is the most considerate Islamic Scholar to define faith. He argued that faith is not just about confessing Allah as the glorified One and the highest One and said admit it verbally, but it has to be accompanied with good deeds (Habsyi, 2010). These Islamic faith indicators are: 1) Feeling under the supervision of Allah; 2) Feeling fear only to Allah; 3) Believing in Allah, Prophet Muhammad and his teachings, Angels, and Quran; 4) Worshipping only Allah; 5) Professing by words expression; 6) Justifying inside the heart; 7) Doing good deeds with all body parts; 8) Doing what is ordered to do; 9) Avoiding what is forbidden; 10) Withstanding in hardship; 11) Feeling agitated with misdeed. According to Imam Baihaqi (from Al-Syafi'i, 2011) in Islamic teaching script "Al-Jāmi’ Li Syu'abil Imān", faith contains from 69 to 77 indicators, with the composition of Islamic faith $35 \%$ to qalb deeds, $10 \%$ words expression deeds, and 55\% physical deeds. It would be ideal to construct a 
faith education measurement tool that contains 69 - 77 faith indicators. However, considering participants emotional and educational level, the questionnaire then only adapts 10 indicators of the Islamic faith.

Some of the items to measure these indicators are "I give an explanation to my child why we should worship Allah and not others", "I tell positive things about Rasulullab", I teach my children to know Qur'an (Ex. Learning to read, memorize al-Qur'an). The measures using a likert scale ranging from $1=$ never until $4=$ frequently. The alpha reliability coefficient for this scale is .935

Children social and emotional skills were measured using 12 items questionnaire which measures three dimensions, persistence, social competence, and self-control. There are several versions of this scale, there is a scale that can be filled by children, but there is also a version that can be filled by parents or teachers, where parents or teachers fill the questionnaire based on their perception about the children's social and emotional skills. This questionnaire is adapted from (Delale-O'Connor, Farley, Lippman, \& Walker, 2012). Self-control, sometimes called self-regulation, refers to the ability to manage one's emotions and behaviors, inhibit negative responses and delay gratification (Bandy \& Moore, 2010). Some of the items to measure self-control is "waited in line patiently" and "sat still when he/she supposed to". The second dimension, persistence, is the capacity to maintain concentration on a task, question, set of directions or interactions, despite distractions and interruptions. Children who show persistence have the ability not only to stay focused on a task but also to overcome setbacks and keep trying. They are able to perform a task or set of tasks with care and effort from start to finish (Delale-O'Connor et al., 2012). Some of the items to measure persistence are "keep working on an activity that was difficult", "work on tasks until they were finished". The third dimension is social competence. It means a student's ability to: 1) take others' perspectives, 2) work well with peers to accomplish a task, 3 ) resolve problems in ways that maximize positive consequences and minimize negative consequences for the student and her/his peers, and 4) behave appropriately according to the situation and social norms. Items to measure this dimension are "Was thoughtful of the feelings of her/his peers", "Understood the feelings of her/his peers". The measures using a likert scale ranging from $1=$ never; until $4=$ frequently. The alpha reliability coefficient for this scale is .867

Data exploration was conducted using One-way ANOVA and Pearson correlation. One way ANOVAs were used to examine differences between Islamic faith education and social emotional skills based on highest education. Correlations were conducted between Islamic faith education and social emotional skills and selected demographic variables (age, gender, participation in routine Islamic forum study). From all the demographics variables considered, there is a significant correlation in giving Islamic faith education between parents who participated in routine Islamic forum study compared to those who did not.

\section{RESULTS AND DISCUSSION Demographic Characteristics}

Participants ranged in age from 27 to 53, with a mean age of 35 years $(\mathrm{SD}=5,2) .52$ participants were involved in the study with males $(11,5 \%)$ and females $(88,5 \%)$. Most of the parents graduated from undergraduate level $(40,5 \%)$ and $65,4 \%$ involved in routine Islamic study forum. There are 20 parents who submitted their children to KAF school, and 32 parents to schools other than KAF. The different number of participant from these two different groups would not affect the result since the data analysis using the mean score and not raw score. 
Table 1. Summary of Findings

\begin{tabular}{lcccc}
\hline \multicolumn{1}{c}{ Variable } & M & SD & \multicolumn{2}{c}{ Correlation coefficient value } \\
\cline { 3 - 5 } & & & $\begin{array}{c}\text { Islamic Faith } \\
\text { Education }\end{array}$ & Social and Emotional Skills \\
\hline Faith education & 103.35 & 15.35 & - & $0.302^{*}$ \\
\hline Social and emotional skills & 36.92 & 6.79 & $.302^{*}$ & - \\
\hline Persistence & 9.4 & 1.94 & $.342^{*}$ & $.775^{*}$ \\
\hline Self-Control & 9.13 & 2.21 & .208 & $.908^{*}$ \\
\hline $\begin{array}{l}\text { Social and emotional } \\
\text { competence }\end{array}$ & 18.38 & 3.73 & .248 & .008 \\
\hline Age & & & & .142 \\
\hline Gender & & & .198 & -.013 \\
\hline $\begin{array}{l}\text { Participation in routine } \\
\text { Islamic Forum Study }\end{array}$ & & $.346^{*}$ & .056 \\
\hline Submitted in KAF & & .253 & .410 \\
\hline Highest education & & .495 & \\
\hline
\end{tabular}

Note: $p<.05 *$; Gender 1 = Male, 2 = Female; Highest education 1= Junior High School, 2= High School, 3= Diploma, 4= Undergraduate, $5=$ Postgraduate, Participation in routine Islamic study forum $1=$ Yes, $2=$ No; Submitted in KAF $1=y e s, 2=$ No

\section{Faith Teaching and Children Social Emotional Skills}

Based on data analysis, it can be concluded that there is a significant correlation between faith education and social and emotional skills, significant at level $\mathrm{p}<.05$. However, the correlation itself is not strong because the correlation value is .302. More specifically, Islamic faith education has a significant correlation with persistence dimension of social and emotional skills $(\mathrm{r}=.342)$. Correlation test also conducted to test whether there is a significant difference of social and emotional skills between children in KAF and from another school. Result showed no significant difference from this test.

The first result aligns with Mackay (2003) that suggest family belief systems, especially those based on spiritual or religious values served as an important means for family members to cope with adversity. The reason that lies between the relationship of religiosity and ability to cope with life stress is that religious beliefs. This belief provides a connection between oneself and higher power, where this connection may include meaningful existence and deity (Forthun, Carannante, \& Diehl, 2015). Evidence from Bartkowski, Xu, \& Levin, (2008) also suggest that religious attendance of parents has a positive effect on child development, particularly pro-social outcomes and that religion functions as protection from conflict.

Other research about religious values and personality among teenagers from Heaven \& Ciarrochi (2007). Their study also supports this notion, where participants higher in hope, joviality, psychological acceptance, and mindfulness tended to be higher in religious values. The reason that lies for this connection could be because of faith. Faith plays an important role to establish a sense of meaning and coping with stressors in life (Henning, 2011). According to Pollner (1989), religious individuals, especially those who held strong intrinsic faith, tend to see the world, the self, and others in 'healthy-mindedness'. McCullough \& Willoughby (2009) also found that religion had a positive correlation with self-control, and Denson, DeWall, Finkel (2012) mentioned there was a negative relationship between selfcontrol and verbal aggressiveness. Low self-control usually associated with behavioral problems, otherwise, students with high self-control usually perform good academic performance (Duckworth \& Seligman, 2005) and having stable and positive interpersonal relations (Stan, 2012)

The explanation for this association is because religious knowledge that someone possesses will influence individual's preferences about human conduct. The knowledge also controls human's behavior (McCullough \& Willoughby, 2009). As an addition, (Johnson, 
2005) stated the faith of "high Gods" correlates positively with positive behaviors, including increasing compliance with community norms. According to McCullough \& Willoughby, (2009), religious cognition is beneficial to facilitate prosocial behavior.

However, the correlation between faith education and social-emotional skills showed low correlation score. The low correlation indicates that children social and emotional skills development are more affected by a lot of broader factors, such as environmental factors, family factors, and also within-child factors such as the difference in temperament, and developmental characteristic (Chen et al., 2014). Temperament differences can explain why some students are able to develop and maintain positive relationships with their environment while others cannot (Miller \& Goldsmith, 2017).

Temperament refers to childrens' inherent personality that reflected in the general habit of their interaction with their environment (Boskic, 2010). This general pattern already formed since birth. According to Thomas and Chess (Thomas, Chess, \& Birch, 1970), child temperament divided into three types (i.e. easy child, difficult child, and slow-to-warm up a child). Easy children are typically happy and easy to adjust to new situations. Difficult children are the ones who have an irregular pattern in their daily habits and have difficulties in adjusting in a new environment. Slow-to-warm child generally is less active children and usually, they also have difficulties to adapt in a new situation.

Other than temperament, the reason for the low correlation between faith education and social and emotional skills is developmental characteristics of early school children. In this age, early grade school children are not attentive to parents directions (Morin, 2013), because at this age they are in transition of enjoying playing with other kids to learn developing social and emotional skills. This indicates that social and emotional skills are not developed enough and the effect of faith education to social and emotional skills needs a longer time to be observed. Based on this explanation, further study in this topic can consider testing the impact of faith teaching with social and emotional skills among more mature children.

Apparently, the low correlation between faith teaching and social and emotional skills can result from the lack of the measurement tool used in this study to measure the frequency of faith teaching. The measurement of Islamic faith education in this study mostly addresses the frequency of parents giving education about the importance of having good interaction between human and Allah (bablun minalläh).

According to Islamic scholars Imam Baihaqi (from Al-Syafi'i, 2011), Islamic faith education also stresses the importance of maintaining good relations among human being (bablun minannās). This relationship implies that humans were taught to show good deeds to other humans through some activities such as to visit someone who is sick, pray and give condolence to those who lost family or relatives, give alms to those who need, etc. The lack of measurement item to measure the social relations is considered to be one of the limitations of this study. Therefore, further study can consider adding items that measure this dimension.

\section{Comparison of children's emotional and social skills among students in KAF and in other schools}

Faith education has a significant role in developing social and emotional skills among children. This study found correlation test results that there is in no significant difference in social and emotional skills among children in KAF and children from other schools. This means that there are other factors that influence children's social and emotional skills, such as parenting style, parents-child quality relationship, and parent's knowledge of children temperament.

Parenting style is parents' typical attitudes and behaviors that produce emotional intensity in an environment where parents raise their children (Darling \& Steinberg, 1993). It plays a significant impact on children's social and emotional development (Aunola, Ruusunen, 
Viljaranta, \& Nurmi, 2015; Hart, Newell, \& Olsen, 2003). For example, affective and warm parenting as indicated in responsive and supportive behavior, combined with appropriate control technique showed by parents, proved to have a significant correlation with low levels of problem behaviors among children. Whilst, strict parental control, controlling children behavior through guilt induction, has been found to be correlated with increased anxiety and distress among children (Barber, 1996; Barber, Stolz, Olsen, Collins, \& Burchinal, 2005). In the same vein with Barber study, other research also revealed that minimizing children's emotional expression, for instance through punishing children, makes them more emotionally reactive and less emotionally in self-regulating (Fabes, Leonard, Kupanoff, \& Martin, 2001; Topham et al., 2011).

Approaches to parenting styles have been typically divided into three dimensions namely affection, behavioral control and psychological control (Aunola \& Nurmi, 2005). Combinations of these dimensions' form three parenting styles namely authoritative parenting, authoritarian parenting, and permissive parenting. Each of the styles contributes to different effects in children (Baumrind, 1971). On the one hand, authoritative parenting is deemed to significantly predict children emotion (Baumrind, 1966; Cunningham, Kliewer, \& Garner, 2009). Permissive and authoritarian parenting, on another side, are related to children's emotional dysfunction, such as poor emotion regulation and aggression strategies (Chang, Schwartz, Dodge, \& McBride-Chang, 2003).

The quality of parents and their relationship with children are viewed as an essential factor to influence children's social and emotional skills. Through a proper relationship with parents, children learn how to express their emotions and understand other people's emotions. This interaction also adds knowledge for children to develop trust, love, and other healthy emotions for their future life (Bretherton, 1992). Many other studies also support this evidence. The study from Paquette (2004) that suggests the degree of emotional bond between father-child and mother-child interaction that developed through physical play. It can contribute to the development of children's skills, and also provide emotional comfort to a certain degree. Positive parents-child interaction also contributes to children's academic success, since children observe rules, learn values, learn how to behave by having interaction with their parents. This notion also consistent with a result from Keogh (2003), that suggests consideration at children's temperament can be useful to educators in creating learning management strategies and interventions to support children and to provide children with varied temperaments equal chance to have academic success. The similar result also is shown by (Wentzel, 2002) that stated parents' knowledge about kids' characteristics play an important role in developing children's social and emotional skills.

Parents' knowledge of their children's temperament is influenced by parent's socioeconomic status. Ramey \& Ramey (2004) explained that there are several factors that may trigger children's poor social-emotional well-being and disrupts early school readiness. Those factors are low income, low maternal education, and status as a single parent. Around $32 \%$ of children in United States, for example, experience one of those demographic risks, and around $16 \%$ of them face two or more (Raver \& Knitzer, 2002).

After analyzing and answering the main hypothesis, this study conducted a test on the correlation between the frequency of giving Islamic faith teaching and demographic variables. The result showed that there is a significant correlation in giving Islamic faith education between parents who participated in routine Islamic forum study and parent who did not. There is no significant correlation with other demographic variables. This result means that the more the parents involved in routine Islamic forum study, the more they show concern and deliver Islamic faith teaching for their children. 
According to (Bornstein et al., 2017), parents with great religiosity had both positive and negative correlations with children. Parent religiosity was associated with higher parental efficacy when their children were 9, and they help children to have better social competence. Another result from (Stokes \& Regnerus, 2008) mentioned that when parent religious values are more than their teenager, their children reported poorer relationship quality with their parents. But relationship quality is not too low when the children also value religions highly. One thing in common from these results is parent religiosity could affect how parents communicate with their children. It also affects children social competence and performance at school. This topic is open for future research.

\section{CONCLUSION}

As a conclusion, there are a significant correlation between teaching Islamic faith and children's social and emotional skills, although the correlation score is relatively low. The low correlation may indicate other factors that contribute more significant impact towards social and emotional skills, such as children temperament and developmental characteristics of early school age children. This study also revealed that there were no significant differences found between children studied in KAF compared to children studied in other schools. This can result from the difference in parent's knowledge of children's temperament, parenting style, and parents-child quality relationship. This study has limitation. There are no controlling factors. Therefore, further study should address those factors.

Other limitations in this study include the possibility of bias result that can be derived from using social and emotional skills scale in this study. Surprisingly, there is a very limited and scarce source of a measurement tool to measure children's social and emotional skills. The scale used in this study could stimulate parent's subjective evaluation of their kids. However, the scale still used in this research for it is more possible to ask parents to fill the questionnaire rather than asking children. The scarcity of measurement tool is also the issue when selecting the appropriate scale to measure parent's intensity, frequency, or commitment to give Islamic faith teaching. Therefore, it will become a challenge to develop such a scale.

Despite the limitations, these results are important especially because there are still very few studies about Islamic faith education to children's outcome, particularly to their social and emotional skills. The result of this research shows that Islamic faith education given by parents at home has a significant correlation to the development of social and emotional skills among children. Faith education can provide a basis for coping and the sense of meaning that can be useful for children to have successful experience in academic or non-academic lives in the future. However, parents also need to develop their understanding towards their kids' temperament uniqueness. Their knowledge about children's temperament could be useful for parents to develop a more suitable approach to educating children at home. Knowledge of children temperament is also essential in order to increase children's goodness of fit. In this context, the degree to which an individual's temperament is confirming the demands and expectations from an individual's social environment. The more children perform their fit, the more they possess the skills to interact with a good manner with other people (Chess \& Thomas, 1991). Landy (2002) suggests varieties of strategies that parents can use to develop their children's social development. Parents can start by observing child's indicator related developmental behavior. Next, they continue to set up an environment to accommodate their children developmental characteristics. Then try to seek any physical characteristics that may contribute to their children's style by applying positive labels to their children, identifying any environmental aspects that can trigger their children's anxiety, and seeking what techniques that can be used to control it. 


\section{BIBLIOGRAPHY}

Al-Syafi'I, Q. (2011). Ringkasan Syu'abul Iman. Jakarta, Indonesia: Pustaka Azzam.

Ashraf, S. A. (1988). The westhill project RE 5-16: Islam: Teacher's manual. London, Mary Glasgow.

Asimov, M. F., \& Bosworth, C. E. (1999). The age of achievement (4th ed.). Motilal Banarsidass.

Aunola, K., \& Nurmi, J. E. (2005). The role of parenting styles in children's problem behavior. Child Development. https://doi.org/10.1111/j.1467-8624.2005.00840.x-i1

Aunola, K., Ruusunen, A. K., Viljaranta, J., \& Nurmi, J. E. (2015). Parental affection and psychological control as mediators between parents' depressive symptoms and child distress. Journal of Family Issues. https://doi.org/10.1177/0192513X13494825

Bandy, T., \& Moore, K. A. (2010). Assessing self-regulation: A guide for out-of-school time program practitioners. Child Trends, 23(10), 1-7. https://doi.org/10.1037/e616952009001

Barber, B. K. (1996). Parental psychological control: Revisiting a neglected construct. Child Development. https://doi.org/10.1111/j.1467-8624.1996.tb01915.x

Barber, B. K., Stolz, H. E., Olsen, J. A., Collins, W. A., \& Burchinal, M. (2005). Parental support, psychological control, and behavioral control: Assessing relevance across time, culture, and method. Monographs of the Society for Research in Child Development. https://doi.org/10.1111/j.1540-5834.2005.00365.x

Bartkowski, J. P., Xu, X., \& Levin, M. L. (2008). Religion and child development: Evidence from the early childhood longitudinal study. Social Science Research. https://doi.org/10.1016/j.ssresearch.2007.02.001

Bauck, P. (2015). Social and emotional learning in religious and spiritual communities: Loving one's Neighbor, (April 2015), 1-4. https://doi.org/10.1016/S01406736(09)61457-4

Baumrind, D. (1966). Effects of Authoritative parental control on child behavior. Child Development. https://doi.org/10.2307/1126611

Baumrind, D. (1971). Current patterns of parental authority. Developmental Psychology. https://doi.org/10.1037/h0030372

Bornstein, M. H., Putnick, D. L., Lansford, J. E., Al-Hassan, S. M., Bacchini, D., Bombi, A. S., ... Alampay, L. P. (2017). "Mixed blessings": parental religiousness, parenting, and child adjustment in global perspective. Journal of Child Psychology and Psychiatry, and Allied Disciplines, 58(8), 880-892. https://doi.org/10.1111/jcpp.12705

Bosetti, L. (2004). Determinants of school choice: Understanding how parents choose elementary schools in Alberta. Journal of Education Policy. https://doi.org/10.1080/0268093042000227465

Boskic, N. (2010). Early Childhood Intervention: Module One - Typical and Atypical Development. Retrieved from http://blogs.ubc.ca/earlychildhoodintervention1/category/1-3-socialand-emotional-development-temperament/

Bretherton, I. (1992). The origins of attachment theory. Developmental Psychology. https://doi.org/10.1037/0012-1649.28.5.759

Bryner, K. (2011). Secular subjects within a religious framework. Retrieved from https://en.qantara.de/node/28

Capps, D. (1995). Religion and mental health. The International Journal for the Psychology of Religion. https://doi.org/10.1207/s15327582ijpr0502_10

Chang, L., Schwartz, D., Dodge, K. A., \& McBride-Chang, C. (2003). Harsh parenting in relation to child emotion regulation and aggression. Journal of Family Psychology. https://doi.org/10.1037/0893-3200.17.4.598 
Chen, N., Deater-Deckard, K., \& Bell, M. A. (2014). The role of temperament by family environment interactions in child maladjustment. Journal of Abnormal Child Psychology. https://doi.org/10.1007/s10802-014-9872-y

Chess, S., \& Thomas, A. (1991). Temperament and the concept of goodness of fit. In Explorations in Temperament. https://doi.org/10.1007/978-1-4899-0643-4_2

Cunningham, J. N., Kliewer, W., \& Garner, P. W. (2009). Emotion socialization, child emotion understanding and regulation, and adjustment in urban African American families: Differential associations across child gender. Development and Psychopathology. https://doi.org/10.1017/S0954579409000157

Darling, N., \& Steinberg, L. (1993). Parenting style as context: An integrative model. Psychological Bulletin. https://doi.org/10.1037/0033-2909.113.3.487

Dawson, G., Ashman, S. B., \& Nelson, C. A. (2000). On the origins of a vulnerability to depression: The influence of the early social environment on the development of psychobiological systems related to risk of affective disorder. The Minnesota Symposia on Child Psychology, Vol 31: The Effects of Early Adversity on Neurobehavioral Development. https://doi.org/10.1017/S0890060408000267

Delale-O'Connor, L., Farley, C., Lippman, L., \& Walker, K. E. (2012). Essential self management skills: Summary of research. (Publication \#2012-27). Child Trends. Retrieved from http://www.childtrends.org/Files//Child_Trends-

2012_09_01_WP_SelfManagement.pdf

Denham, S. A., \& Weissberg, R. P. (2004). Social-emotional learning in early childhood: What we know and where to go from here. In A blueprint for the promotion of prosocial behavior in earlychildhood (E. Chesebr, pp. 13-50). New York: Kluwer/Plenum.

Duckworth, A. L., \& Seligman, M. E. P. (2005). Self-discipline outdoes IQ in predicting academic performance of adolescents. Psychological Science. https://doi.org/ 10.1111/j.1467-9280.2005.01641.x

Elias, A. A. (2011). Hadith on responsibility: Each of you is a Shepherd responsible for his flock. Retrieved from http://dailyhadith.abuaminaelias.com/2011/07/03/each-one-ofyou-is-a-shepherd-responsible-for-his-or-her-flock

Fabes, R. A., Leonard, S. A., Kupanoff, K., \& Martin, C. L. (2001). Parental coping with children's negative emotions: Relations with children's emotional and social responding. Child Development. https://doi.org/10.1111/1467-8624.00323

Forthun, L. F., Carannante, S., \& Diehl, D. C. (2015). Strengthening families: Parental resilience 1. Strenghthening Family Series, 1-3.

Habsyi, I. (2010). Konsep Iman Menurut Ibn Taimiyyah. UIN Syarif Hidayatullah. Retrieved from http://repository.uinjkt.ac.id/dspace/bitstream/123456789/4626/1/IDRUS HABSYIFUH.pdf

Hart, C. H., Newell, L. D., \& Olsen, S. F. (2003). Parenting skills and social-communicative competence in childhood. In Handbook of Communication and Social Interaction Skills. https://doi.org/10.1007/978-90-481-9775-0_1

Heaven, P. C. L., \& Ciarrochi, J. (2007). Personality and religious values among adolescents: A three-wave longitudinal analysis. British Journal of Psychology, 98(4), 681-694. https://doi.org/10.1348/000712607X187777

Henning, D. (2011). Psychological development \& meaningful faith: When faith works, 1-12. Retrieved from http://www.cslewis.org/journal/psychological-development-meaningfulfaith-when-faith-works/view-all/

Hertel, B. R., \& Donahue, M. J. (1995). Parental influences on God images among children: Testing Durkheim's Metaphoric Parallelism. Journal for the Scientific Study of Religion, 34(2), 186. https://doi.org/10.2307/1386764 
Johnson, D. D. P. (2005). Human nature / winter 2005 God's punishment and public goods a test of the supernatural punishment bypothesis in 186 world cultures. Human Nature (Vol. 16). Retrieved from https://www.the-brights.net/morality/ statement_3_studies/ DOI/10.1007_s 12110-005-1017-0. pdf

Keogh, B. Kp. H. B. P. C. (2003). Temperament in the classroom: Understanding individual differences. Baltimore, MD: Paul H. Brookes Publishing Co.

Landry, S. H. (2017). The role of parents in early childhood learning. Encyclopedia on Early Childhood Development. Texas, USA. Retrieved from http://www.child-encyclopedia.com/

Landy, S. (2002). Pathways to competence: Encouraging healthy social and emotional development in young children. Baltimore, MD: Paul H. Brookes Publishing Co.

Lerner, R. M., \& Castellino, D. R. (2002). Contemporary developmental theory and adolescence: Developmental systems and applied developmental science. Journal of Adolescent Health. https://doi.org/10.1016/S1054-139X(02)00495-0

Mackay, R. (2003). Family resilience and good child outcomes: An overview of the research literature . Social Policy Journal of New Zealand. https://doi.org/10.1.1.524.7223

McCullough, M. E., \& Willoughby, B. L. B. (2009). Religion, self-regulation, and self-control: Associations, explanations, and implications. Psychological Bulletin. https://doi.org $/ 10.1037 / \mathrm{a} 0014213$

McIntosh, D. N., Silver, R. C., \& Wortman, C. B. (1993). Religion's role in adjustment to a negative life event: Coping with the loss of a child. Journal of Personality and Social Psychology. https://doi.org/10.1037/0022-3514.65.4.812

Mey, I. (2005). The cultural nature of human development (Barbara Rogoff ). Journal of Linguistic Anthropology. https:/ / doi.org/10.1525/jlin.2005.15.2.290

Miller, M. M., \& Goldsmith, H. H. (2017). Profiles of social-emotional readiness for 4-year-old kindergarten. Frontiers in Psychology. https://doi.org/10.3389/ fpsyg.2017.00132

Morin, A. (2013). Social and emotional skills: What to Expect at Different Ages.

NCPFCE. (2015). Positive parent-child relationships.

Paquette, D. (2004). Theorizing the father-child relationship: Mechanisms and developmental outcomes. Human Development. https://doi.org/10.1159/000078723

Park, C. L. (2005). Religion as a meaning-making framework in coping with life stress. Journal of Social Issues. https:// doi.org/10.1111/j.1540-4560.2005.00428.x

Pollner, M. (1989). Divine relations, social relations, and well-being. Journal of Health and Social Behavior. https://doi.org/10.2307/2136915

Ramey, C. T., \& Ramey, S. L. (2004). Early learning and school readiness: Can Early intervention make a difference? Merrill-Palmer Quarterly. https://doi.org/10.1353 /mpq.2004.0034

Raver, C. C., \& Knitzer, J. (2002). Ready to enter: What research tells policymakers about strategies to promote social and emotional school readiness among three- and four-year-old children. Promoting the emotional well-being of children and families: Policy paper no. 1.

Richert, R. A., \& Barrett, J. L. (2005). Do you see what I see? Young children's assumptions about god's perceptual abilities. The International Journal For The Psychology of Religion, 15(4), 283-295. Retrieved from https://ccl.ucr.edu/wp-content/uploads/2015/08 /RichertBarrett2005.pdf

Rosa, D. A. D. La. (1998). Why alternative education works. The High School Journal, 81(4), 268-272. https://doi.org/10.2307/40364474

Schonhardt, S. (2013). Indonesia envisions more religion in schools. Retrieved from https://www.nytimes.com/2013/01/07/world/asia/in-indonesia-science-may-give-wayto-religion.html 
Songer, N. (2009). Understanding social and emotional development in young children. MidState Central Early Childhood Direction Center Bulletin, 1-8. Retrieved from http://ecdc.syr.edu/wp-content/uploads/2013/01/

Stan, M. M. (2012). The role of parental styles the socio-emotional competence of children at the beginning of school years. In Procedia - Social and Behavioral Sciences. https://doi.org/10.1016/j.sbspro.2012.01.234

Stokes, C. E., \& Regnerus, M. D. (2008). When faith divides family: Religious discord and adolescent reports of parent-child relations q. https://doi.org/ 10.1016/j.ssresearch.2008.05.002

Thomas, A., Chess, S., \& Birch, H. G. (1970). The origin of personality. Scientific American. https://doi.org/10.1038/scientificamerican0870-102

Topham, G. L., Hubbs-Tait, L., Rutledge, J. M., Page, M. C., Kennedy, T. S., Shriver, L. H., \& Harrist, A. W. (2011). Parenting styles, parental response to child emotion, and family emotional responsiveness are related to child emotional eating. Appetite. https://doi.org/10.1016/j.appet.2011.01.007

Wahyudi, A. (2012). Definisi Iman. Retrieved from https://muslim.or.id/8631-definisiiman.html

Weber, S. R., \& Pargament, K. I. (2014). The role of religion and spirituality in mental health. Current Opinion in Psychiatry. https://doi.org/10.1097/YCO.0000000000000080

Weigel, D. J., Martin, S. S., \& Bennett, K. K. (2006). Mothers' literacy beliefs: Connections with the home literacy environment and pre-school children's literacy development. Journal of Early Childhood Literacy, 6(2), 191-211. https://doi.org/10.1177/ 1468798406066444

Wentzel, K. R. (2002). Are effective teachers like good parents? Teaching styles and student adjustment in early adolescence. Child Development. https://doi.org/10.1111/14678624.00406 